\title{
Mucin phenotypic expression and background mucosa of esophagogastric junctional adenocarcinoma
}

\author{
Naoko Tsuji ${ }^{1,4}$, Shingo Ishiguro ${ }^{1}$, Yoshitane Tsukamoto ${ }^{1}$, Masayuki Mano ${ }^{1}$, Tsutomu Kasugai ${ }^{1}$, \\ Isao Miyashiro ${ }^{2}$, Yuichiro Doki ${ }^{2}$, Hiroyasu IsShI $^{3}$, and Masatoshi $\mathrm{Kudo}^{5}$ \\ ${ }^{1}$ Department of Pathology, Osaka Medical Center for Cancer and Cardiovascular Diseases, 1-3-3 Nakamichi, Higashinari-ku, \\ Osaka 537-8511, Japan \\ ${ }^{2}$ Department of Surgery, Osaka Medical Center for Cancer and Cardiovascular Diseases, Osaka, Japan \\ ${ }^{3}$ Department of Gastroenterology, Osaka Medical Center for Cancer and Cardiovascular Diseases, Osaka, Japan \\ ${ }^{4}$ Department of Gastroenterology, Sakai Hospital, Kinki University School of Medicine, Sakai, Japan \\ ${ }^{5}$ Department of Gastroenterology and Hepatology, Kinki University School of Medicine, Osaka-sayama, Japan
}

\begin{abstract}
Background. In the West, the incidence of adenocarcinoma of the cardia or esophagogastric junction (EGJ) is increasing. This carcinoma is variously defined, however, and it contains heterogeneous tumors. In Japan, the frequency of this carcinoma is low, and little is known about it. We studied small esophagogastric junctional adenocarcinoma to determine its characteristics in Japanese patients.

Methods. Fifty-four patients with Siewert type II junctional adenocarcinoma (with tumors $<4 \mathrm{~cm}$ in maximum diameter) were studied. The carcinomas were classified into two types: tumors straddling the EGJ (EGJ-type) and tumors occurring entirely below the EGJ (bEGJ-type). Characteristics of the tumors and surrounding mucosae were evaluated. Phenotypic expression of mucin, p53 overexpression, and Helicobacter pylori infection were investigated histologically and immunohistochemically.

Results. Twenty-three (43\%) patients had EGJ-type and 31 (57\%) had bEGJ-type carcinomas. The ratio of advanced cancers was significantly higher in EGJ-type. Some betweengroup similarities and differences existed in histological type, mucin phenotype, and p53 protein overexpression, but they were not statistically significant. In the mucosa surrounding EGJ-type tumors vs bEGJ-type tumors, oxyntic glands were significantly better preserved, gastric intestinal metaplasia occurred significantly less frequently, and the $H$. pylori infection rate was lower. Barrett's metaplasia was seen in only 2 patients, with the EGJ-type.

Conclusion. EGJ-type and bEGJ-type adenocarcinomas have different background mucosa of the stomach. EGJ-type has less atrophy of the oxyntic glands and less intestinal metaplasia in the stomach. This type appears to be the Western-type junctional adenocarcinoma that is still rare in Japan. Many cases of advanced junctional adenocarcinoma in Japan are of subjunctional origin.
\end{abstract}

Key words EGJ adenocarcinoma $\cdot$ Background mucosa

Offprint requests to: $\mathrm{N}$. Tsuji

Received: June 19, 2003 / Accepted: February 6, 2004

\section{Introduction}

The incidence of adenocarcinoma at the esophagogastric junction (EGJ) has increased in the West [1-4]. Some reports indicate that the same trend is occurring in Japan [5], but adenocarcinoma of the EGJ is still rare here, and adenocarcinoma of the esophagus is even rarer. The definition of adenocarcinoma of the EGJ is obscure, and in many advanced cancer cases, it is difficult to know whether the tumor is junctional in origin or a result of invasion to the EGJ from sites distal or proximal to it. To investigate junctional cancers, we studied cases of adenocarcinoma that fulfill Siewert's type II criterion (being tumors the center of which is located within $1 \mathrm{~cm}$ oral and $2 \mathrm{~cm}$ distal of the anatomical EGJ) [6]. We investigated tumors less than $4 \mathrm{~cm}$ in maximum diameter, because the architecture of the EGJ was still preserved in the presence of such small tumors, and the background mucosae of the carcinoma, in terms of the squamocolumnar junction (SCJ), cardiac glands, oxyntic glands, intestinal metaplasia, and Barrett's epithelium, were easily studied. We also investigated p53 protein overexpression, because significantly high levels of p53 mutations and p53 protein overexpression in cardia and esophageal adenocarcinomas have been reported in the West [7,8]. In this study, we investigated the characteristics of junctional carcinoma and background mucosa in Japanese patients to find the similarities with and differences from Western patients.

Patients and methods

Patients and definition of the EGJ

The study population comprised 54 patients (45 men and 9 women) who had undergone esophago- 
gastrectomy for adenocarcinoma of Siewert type II tumors of the EGJ at Osaka Medical Center for Cancer and Cardiovascular Diseases. All tumors were smaller than $4 \mathrm{~cm}$ in maximum diameter, and the center of the tumors arose between $1 \mathrm{~cm}$ oral and $2 \mathrm{~cm}$ distal of the EGJ. All patients were treated by surgery alone; none underwent preoperative chemotherapy or radiation

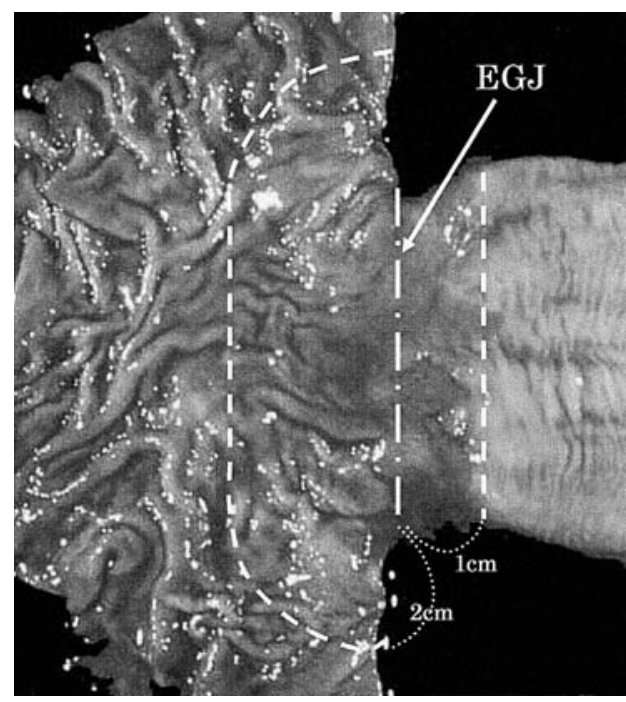

Fig. 1. Photograph of the exophagogastric junction $(E G J)$ in a patient with short segment Barrett's esophagus. We defined the EGJ as the area where the tubular esophagus joins the saccular stomach (center line). Siewert type II junctional adenocarcinoma is that which arises between $1 \mathrm{~cm}$ oral (right line) and $2 \mathrm{~cm}$ distal (left line) of the EGJ therapy. Gross specimens were opened along the longitudinal axis of the stomach. We identified the EGJ in resected materials to be where the tubular esophagus joins the saccular stomach (Fig. 1), and the SCJ was the visible line formed by the juxtaposition of squamous and columnar epithelia. The carcinomas were classified into two types: tumors straddling the EGJ (EGJ-type; Fig. 2A), and tumors occurring entirely below the EGJ (bEGJ-type; Fig. 2B).

All specimens were fixed in $10 \%$ formalin and cut serially into 5-mm slices parallel with the lesser curvature. All tissue sections were stained with hematoxylineosin. Tumors were characterized by gross type, histological type, depth of invasion, and lymph node involvement. Barrett's epithelium was diagnosed when columnar epithelium was continuously found from the EGJ to the distal esophagus, and Barrett's metaplasia was diagnosed only when incomplete intestinal metaplasia was found in Barrett's epithelia. The state of the oxyntic gland was also evaluated. Atrophy of the oxyntic gland was graded into four categories: none, mild, moderate, and severe atrophy. The "none" and "mild" categories were considered as negative and the "moderate" and "severe" categories were considered as positive for atrophy. Intestinal metaplasia of the stomach was also evaluated. If intestinal metaplasia was detected in none to a few slides of the stomach tissue, patients with this finding were considered negative for intestinal metaplasia. If intestinal metaplasia was detected in many to all slides of the stomach tissue, patients with this finding were considered positive for intestinal metaplasia.
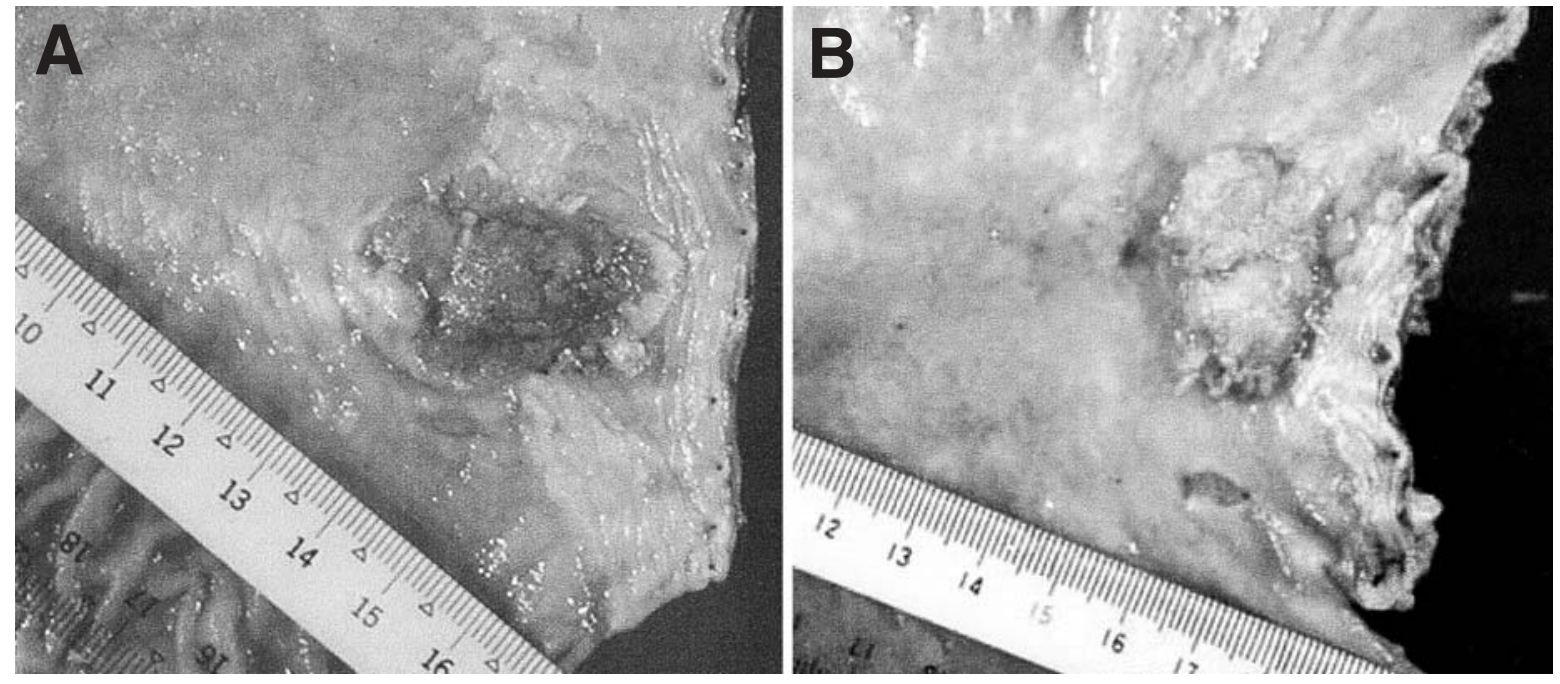

Fig. 2A,B. Photographs of specimens from a patient with an EGJ-type tumor (A) and a patient with a bEGJ-type tumor (B). A EGJ-type tumor straddles the EGJ. The squamocolumnar junction and EGJ coincide. B bEGJ-type tumor remains completely below the EGJ 


\section{Mucin histochemistry and immunohistochemistry}

To evaluate the cancer-cell phenotype, samples of each tumor, obtained from the area of maximum diameter, were selected, and mucin histochemistry and immunohistochemistry were performed. For mucin histochemistry, paradoxical concanavalin A class III (ConA III; mucin of the mucous neck cells/pyloric gland cells) was used [9]. For immunohistochemistry, human gastric mucin (Novocastra, Newcastle, UK; diluted 1:200; mucin of the surface gastric epithelium), CD10 (Novocastra; diluted 1:500; brush border of gut epithelial cells), and Muc-2 glycoprotein (Novocastra; diluted 1:400; intestinal mucin) were used. The avidin-biotin-peroxidase complex (ABC) immunohistochemistry method (Vectastatin Elite ABC Kit; Vector Laboratories, Burlingame CA, USA) was used. Human gastric mucin- or ConA III-positive cancer cells were classified as gastric-type cells, and CD10- or Muc2 glycoprotein-positive cancer cells were classified as intestinal-type cells. Tumors consisting only of gastrictype cells were classified as gastric-type tumors, and those consisting only of intestinal-type cells were classified as intestinal-type tumors. Tumors consisting of both cell types were classified as mixed-type tumors. Tumors showing no reaction to any of the stains were classified as unknown type. The p53 protein expression of the tumor cells was determined immunohistochemically by staining with DO7 antibody (Dako, Glostrup, Denmark, diluted 1:100). Helicobacter pylori infection was studied by both immunohistochemical staining of selected sections and hematoxylin-eosin staining of all sections. Rabbit antiH. pylori antibodies (Dako; diluted 1:100) were used after proteinase $\mathrm{K}$ digestion.

\section{Statistical methods}

Frequencies of various characteristics were compared between groups, and the $\chi^{2}$ test with Fisher's exact test was used to test for statistical differences. Statistical significance was accepted at a $P$ value of less than 0.05 .

\section{Results}

\section{Patient characteristics}

The clinicopathological characteristics of all 54 patients are shown in Table 1. There were 23 (43\%) EGJ-type patients and $31(57 \%)$ bEGJ-type patients. The average age of all patients was 64 years (range, 45-80 years); $52 \%$ of the EGJ-type patients and $74 \%$ of the bEGJtype were aged 60 years or more. Men comprised $78 \%$ of the EGJ-type patients and $87 \%$ of the bEGJ-type patients.

\section{Tumor characteristics}

The frequency of advanced cancer was significantly higher in EGJ-type tumors than in bEGJ-type tumors (52\% in EGJ-type vs $26 \%$ in bEGJ-type; $P<0.05$ ). Most of the advanced gastric cancers in the EGJ-type carcinomas were grossly identified as type-2 tumors. Histologically, $65 \%$ of EGJ-type and $58 \%$ of bEGJtype carcinomas were classified as tubular adenocarcinoma. Signet ring cell carcinoma was seen in only one patient, with a bEGJ-type tumor. Ninety percent of bEGJ-type cancers and $61 \%$ of EGJ-type cancers were node-negative (Table 1).

Phenotypic expression of mucin, and mucin and p53 expression in the tumor cells

Twelve of 23 (52\%) EGJ-type tumors expressed human gastric mucin, whereas only $29 \%$ of bEGJ-type tumors did so. About $55 \%$ of both tumor types expressed Muc2 glycoprotein. (Table 2) Thirty-nine percent of EGJtype tumors were of the mixed gastric and intestinal phenotype (Table 3; Fig. 3A-D), whereas 38\% of bEGJ-type tumors were of the intestinal phenotype (Table 3; Fig. 4A-C). p53 protein was detected in 78\%

Table 1. Patient and clinicopathological characteristics

\begin{tabular}{|c|c|c|}
\hline & $\begin{array}{c}\text { EGJ-type } \\
23(\%)\end{array}$ & $\begin{array}{c}\text { bEGJ-type } \\
31(\%)\end{array}$ \\
\hline \multicolumn{3}{|l|}{ Sex } \\
\hline Male & $18(78)$ & $27(87)$ \\
\hline Female & $5(22)$ & $4(13)$ \\
\hline \multicolumn{3}{|l|}{ Age(years) } \\
\hline$<60$ & $11(48)$ & $8(26)$ \\
\hline$\geqq 60$ & $12(52)$ & $23(74)$ \\
\hline \multicolumn{3}{|l|}{ Gross pathology } \\
\hline Superficial type & $11(48)$ & $23(74)^{*}$ \\
\hline Advanced type & $12(52)$ & $8(26)$ \\
\hline Type 1 & 0 & 2 \\
\hline Type 2 & 9 & 2 \\
\hline Type 3 & 3 & 4 \\
\hline Type 4 & 0 & 0 \\
\hline \multicolumn{3}{|l|}{ Histologic type } \\
\hline Papillary & $4(17)$ & $7(23)$ \\
\hline Tubular & $15(65)$ & $18(58)$ \\
\hline Poorly differentiated & $2(9)$ & $4(13)$ \\
\hline Mucinous & $2(9)$ & $1(3)$ \\
\hline Signet ring & $0(0)$ & $1(3)$ \\
\hline \multicolumn{3}{|l|}{ Depth of invasion } \\
\hline $\mathrm{T} 1$ & $11(48)$ & $23(74)$ \\
\hline $\mathrm{T} 2$ & $5(22)$ & $8(26)$ \\
\hline $\mathrm{T} 3$ & $7(30)$ & $0(0)$ \\
\hline \multicolumn{3}{|l|}{ Lymph node involvement } \\
\hline No & $14(61)$ & $28(90)^{*}$ \\
\hline $\mathrm{N} 1-2$ & $9(39)$ & $3(10)$ \\
\hline
\end{tabular}

$* P<0.05$

EGJ-type, tumors straddling the esophagogastric junction; bEGJtype, tumors occurring entirely below the EGJ 

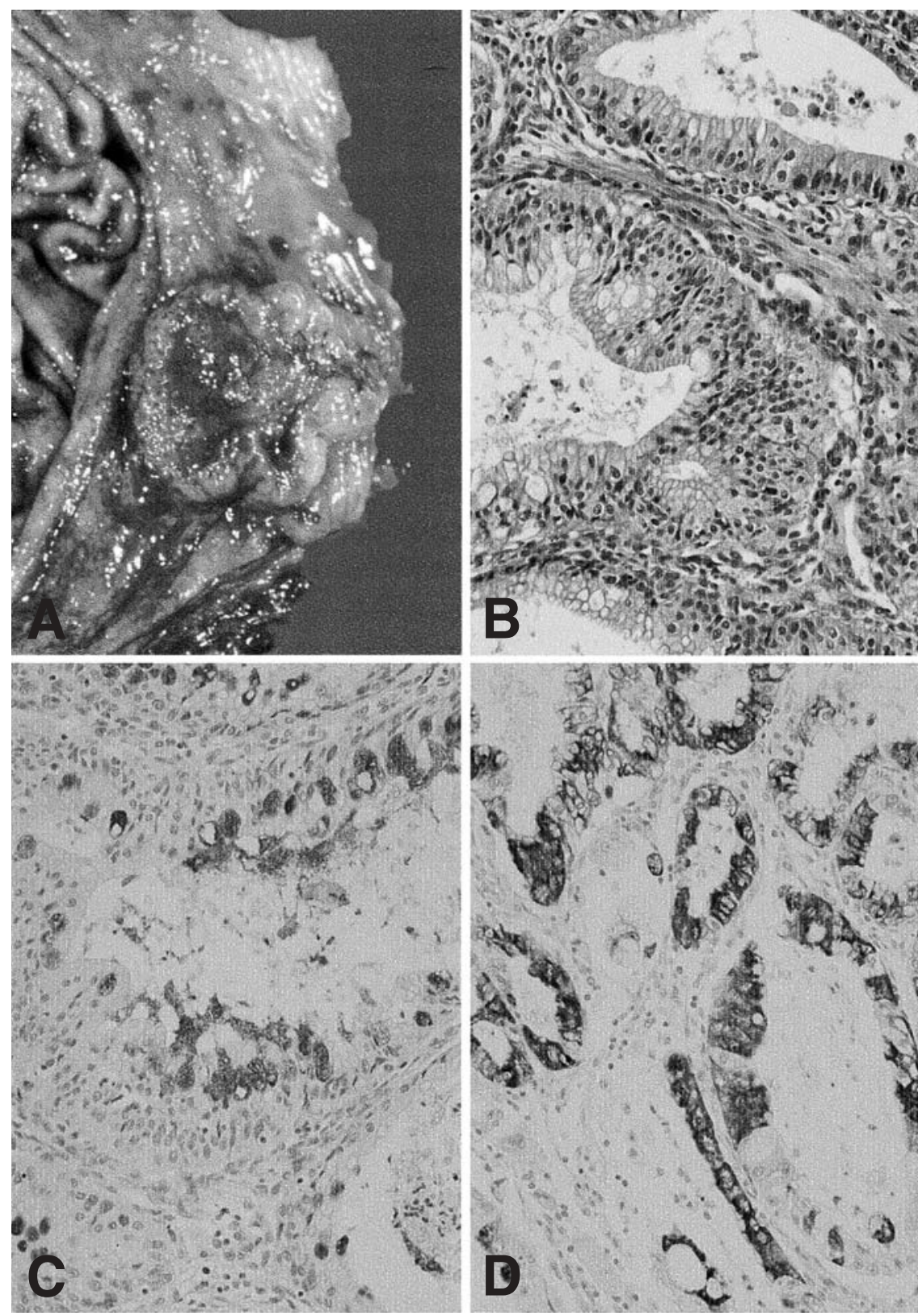

Fig. 3. A An EGJ-type resected specimen. Small type-2 tumor straddles the EGJ. B Histology shows well-differentiated tubular adenocarcinoma. C This tumor reacted with human gastric mucin and also with Muc-2 glycoprotein (D). B H\&E, $\times 200 ; \mathbf{C} \times 200 ; \mathbf{D} \times 200$
Table 2. Mucin histochemistry of EGJ adeno-carcinoma

\begin{tabular}{ccr}
\hline & $\begin{array}{c}\text { EGJ-type } \\
23(\%)\end{array}$ & $\begin{array}{r}\text { bEGJ-type } \\
31(\%)\end{array}$ \\
\hline $\begin{array}{c}\text { Gastric mucin } \\
+\end{array}$ & $12(52)$ & \\
- & $11(48)$ & $22(29)$ \\
$\begin{array}{c}\text { ConA III } \\
+\end{array}$ & $1(4)$ & $4(13)$ \\
- & $22(96)$ & $27(87)$ \\
$\begin{array}{c}\text { Muc2 } \\
+\end{array}$ & $13(57)$ & $17(55)$ \\
- & $10(43)$ & $14(45)$ \\
CD10 & $5(22)$ & $9(29)$ \\
+ & $18(78)$ & $22(71)$ \\
- & &
\end{tabular}

Table 3. Phenotypic expression of mucin in EGJ adenocarcinoma

\begin{tabular}{lcr}
\hline & $\begin{array}{c}\text { EGJ-type } \\
23(\%)\end{array}$ & $\begin{array}{r}\text { bEGJ-type } \\
31(\%)\end{array}$ \\
\hline Gastric type & $4(17)$ & $4(13)$ \\
Mixed type & $9(39)$ & $8(26)$ \\
Intestinal type & $7(30)$ & $12(38)$ \\
Unknown & $3(13)$ & $7(23)$ \\
\hline
\end{tabular}



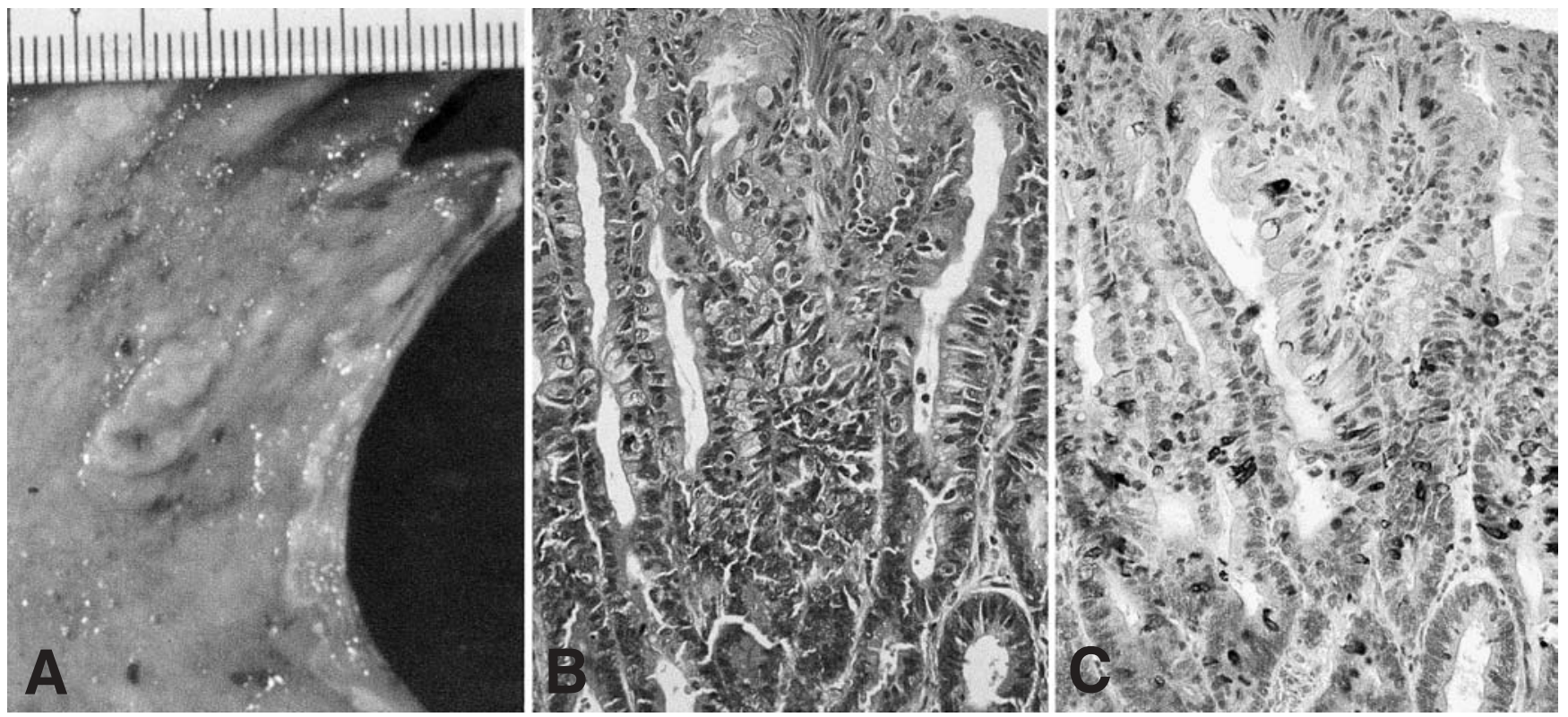

Fig. 4. A bEGJ-type resected specimen. Small IIa-type tumor is within $2 \mathrm{~cm}$ distal of the EGJ. B Histology shows welldifferentiated tubular adenocarcinoma. C This tumor reacted only with Muc-2 glycoprotein. B H\&E, ×200; C ×200

Table 4. p53 overexpression in EGJ adenocarcinoma

\begin{tabular}{lcc}
\hline & EGJ-type & b-EGJ-type \\
p53 & $23(\%)$ & $31(\%)$ \\
\hline+ & $18(78)$ & $17(55)$ \\
- & $5(22)$ & $14(45)$ \\
\hline
\end{tabular}

of EGJ-type tumors and 55\% of bEGJ-type tumors (Table 4); none of these differences were statistically significant (Tables 2, 3, 4).

\section{Surrounding mucosa}

The SCJ and EGJ coincided in 48 of the 54 (89\%) patients. Six patients $(11 \%)$ had tongue-like or circular Barrett's epithelia. Barrett's metaplasia was seen in only 2 patients, with EGJ-type tumors, and both were of the short-segment Barrett's esophagus type. Cardiac glands around the EGJ were seen in most cases. Extension of cardiac glands distal to the EGJ was from $2 \mathrm{~mm}$ to $16 \mathrm{~mm}$, and oral extension into the distal esophagus was from $0 \mathrm{~mm}$ to $10 \mathrm{~mm}$. Atrophy of the oxyntic glands was significantly less frequent in EGJ-type than in bEGJ-type patients (26\% of EGJ-type vs $77 \%$ of bEGJtype; $P<0.01$ ). Intestinal metaplasia of the stomach was also significantly less frequent in EGJ-type patients $(22 \%$ vs $52 \% ; P<0.05)$. H. pylori infection was seen in $26 \%$ of EGJ-type and $35 \%$ of bEGJ-type patients (Table 5). Dysplasia within Barrett's metaplasia was not
Table 5. Characteristics of the mucosa surrounding EGJ adenocarcinoma

\begin{tabular}{lrc}
\hline & EGJ-type & bEGJ-type \\
& $23(\%)$ & $31(\%)$ \\
\hline Atrophy of oxyntic gland & & \\
+ & $6(26)$ & $24(77)^{*}$ \\
$\quad-$ & $17(74)$ & $7(23)$ \\
$\begin{array}{l}\text { Intestinal metaplasia of the stomach } \\
\quad+\end{array}$ & $5(22)$ & $16(52)^{* *}$ \\
$\quad$ & $18(78)$ & $15(48)$ \\
$\begin{array}{l}\text { Barrett's metaplasia } \\
+\end{array}$ & $2(9)$ & $0(0)$ \\
- & $21(91)$ & $31(100)$ \\
Helicobacter pylori & $6(26)$ & $11(35)$ \\
+ & $17(74)$ & $20(65)$ \\
- &
\end{tabular}

$* P<0.01 ; * * P<0.05$

observed. In one case patient with signet ring cell carcinoma, dense oxyntic glands were seen in the surrounding mucosa.

\section{Discussion}

The gastric cardia or gastroesophageal junction is a vague anatomical area; foveolar epithelium, stratified squamous epithelium, and in some cases, intestinal metaplasia are seen, and cardiac and oxyntic glands are also seen in this area. Some investigators believe that cardiac mucosa is not normal mucosa but, rather, 
mucosa acquired as a result of gastroesophageal reflux [10]. Gastroesophageal reflux disease (GERD) occurs less frequently in Japan than in the Western world, but in our study, cardiac mucosa was seen in most patients. Distal extension of cardiac glands from the EGJ was from $2 \mathrm{~mm}$ to $16 \mathrm{~mm}$ in our study, and cardiac mucosa appeared to occupy only a small part of Siewert's type II areas, as other investigators have also reported [11-13]. With regard to the sex and age of patients with EGJ adenocarcinoma in the Western world, a strong predilection exists for middle-aged and older white men $[14,15]$; likewise, in our Japanese series, both EGJ- and bEGJ-type patients were predominantly old men. Many of the EGJ-type carcinomas were advanced cancers, and the ratio of type-2 carcinoma was high, indicating that EGJ-type carcinomas tend to have a penetrating, expansive growth pattern, whereas bEGJ-type carcinomas tend to have a superficial spreading growth pattern. Microscopically, both types of carcinomas were predominantly well differentiated, and signet ring cell carcinoma was not found in any EGJ-type patients.

The phenotypic expression of mucin was also slightly different between the EGJ- and bEGJ-type carcinomas. Tajima et al. [16] reported high positivity for gastric phenotype markers alone in early adenocarcinoma of the gastric cardia. Of our EGJ-type tumors, $52 \%$ reacted with human gastric mucin, but many of them also reacted with intestinal mucin, and many of the bEGJtype tumors were of the pure intestinal phenotype. High levels of p53 protein expression have been reported in gastric cardia tumors $(56 \%-65 \%)$ and also in esophageal adenocarcinoma (59\%), in comparison to levels in adenocarcinoma of the antrum $(27 \%)$ [7,8]. In the present series, $78 \%$ of the EGJ-type and $55 \%$ of bEGJtype tumors expressed p53 protein. The percentage of p53 protein expression was higher in EGJ-type and lower in bEGJ-type carcinomas in comparison with findings in other studies.

In the gastric mucosa of EGJ-type tumors vs that of bEGJ-type tumors, oxyntic glands were better preserved, intestinal metaplasia was less frequent, and the $H$. pylori infection rate was lower. In distal gastric cancer, H. pylori infection, chronic atrophic gastritis, and intestinal metaplasia are thought to constitute the pathway to carcinogenesis [17]. EGJ-type tumors appear to be not related to this pathway, and they expressed p53 protein. These characteristics are similar to those of cardia adenocarcinoma in Western patients, but in our series, Barrett's metaplasia was detected in only two patients $(3.8 \%)$, and the frequency of Barrett's metaplasia is much less in Japanese than in Western people $(13 \%-42 \%)$ [18-20]. In the present study of small Siewert type II junctional cancers, the number of tumors that did not cross the EGJ (bEGJ-type) was larger than the number that did (EGJ-type). This type of tumor may cross the EGJ through tumor extension. The advanced junctional cancer in many Japanese patients appears to originate from subjunctional mucosa. The $H$. pylori infection rate is now very high in the Japanese population, and eradication therapy has just begun to be used routinely. Fortunately, the infection rate in the younger generation in Japan is low. The incidence of EGJ-type may increase in the near future, but at present we do not know whether the incidence of junctional adenocarcinoma either with or without Barrett's metaplasia will increase.

In conclusion, there are two different type of EGJ adenocarcinoma in Japan, based on different associations with atrophy and intestinal metaplasia of the stomach. EGJ-straddling tumors have less intestinal metaplasia and oxyntic gland atrophy of the stomach than tumors occurring entirely below the EGJ. EGJstraddling tumors appear to be the Western-type junctional adenocarcinoma that is still rare in Japan. Many cases of advanced junctional adenocarcinoma in Japan are of subjunctional origin.

\section{References}

1. Powell J, McConkey CC. Increasing incidence of adenocarcinoma of the gastric cardia and adjacent sites. Br J Cancer 1990;62:4403.

2. Blot WJ, Devesa SS, Kneller RW, Fraumeni JF Jr. Rising incidence of adenocarcinoma of the esophagus and gastric cardia. JAMA 1991;265:1287-9.

3. Pera M, Cameron AJ, Trastek VF, Carpenter HA, Zinsmeister AR. Increasing incidence of adenocarcinoma of the esophagus and esophagogastric junction. Gastroenterology 1993;104:510-3.

4. Devesa SS, Blot WJ, Fraumeni JF Jr. Changing patterns in the incidence of esophageal and gastric carcinoma in the United States. Cancer 1998;83:2049-53.

5. Okabayashi T, Gotoda T, Kondo H, Inui T, Ono H, Saito D, et al. Early carcinoma of the gastric cardia in Japan: is it different from that in the West? Cancer 2000;89:2555-9.

6. Siewert JR, Stein HJ. Carcinoma of the cardia: carcinoma of the gastroesophageal junction-classification, pathology and extent of resection. Dis Esophagus 1996;9:173-82.

7. Ireland AP, Shibata DK, Chandrasoma P, Lord RV, Peters JH, DeMeester TR. Clinical significance of p53 mutations in adenocarcinoma of the esophagus and cardia. Ann Surg 2000;231:17987.

8. Gleeson CM, Sloan JM, McManus DT, Maxwell P, Arthur K, McGuigan JA, et al. Comparison of p53 and DNA content abnormalities in adenocarcinoma of the oesophagus and gastric cardia. Br J Cancer 1998;77:277-86.

9. Katsuyama T, Spicer SS. Histochemical differentiation of complex carbohydrates with variants of the concanavalin Ahorseradish peroxidase method. J Histochem Cytochem 1978;26: 233-50.

10. Chandrasoma PT, Der R, Ma Y. Histology of the gastroesophageal junction: an autopsy study. Am J Surg Pathol 2000;24:40229.

11. Spechler SJ. The role of gastric carditis in metaplasia and neoplasia at the gastroesophageal junction. Gastroenterology 1999;117: 218-28.

12. Ormsby AH, Goldblum JR, Kilgore SP, Richter JE, Rice TW, Falk GW, et al. The frequency and nature of cardiac mucosa and 
intestinal metaplasia (IM) of the esophagogastric junction (EGJ): a population based study of 223 consecutive autopsies (abstract). Gastroenterology 1999;116:A273.

13. Kilgore SP, Ormsby AH, Gramlich TL, Rice TW, Richter JE, Falk GW, et al. The gastric cardia is not a metaplastic mucosa secondary to gastroesophageal reflux disease (GERD) (abstract). Gastroenterology 1999;116:A213.9.

14. Morales TG, Sampliner RE, Bhattacharyya A. Intestinal metaplasia of the gastric cardia. Am J Gastroenterol 1997;3:414-8.

15. MacDonald WC, MacDonald JB. Adenocarcinoma of the esophagus and/or gastric cardia. Cancer 1987;60:1094-8.

16. Tajima Y, Nakanishi Y, Yoshino T, Kokawa A, Kusano M, Shimoda T. Clinicopathological study of early adenocarcinoma of the gastric cardia: comparison with early adenocarcinoma of the distal stomach and esophagus. Oncology 2001:62;1-9.
17. Correa P. Human gastric carcinogenesis: multistep and multifactorial process-First American Cancer Society Award Lecture on Cancer Epidemiology and Prevention. Cancer Res 1992: 52;673540.

18. Cameron AJ, Lomboy CT, Pera M, Carpenter HA. Adenocarcinoma of the esophagogastric junction and Barrett's esophagus. Gastroenterology 1995;109:1541-6.

19. Clark GW, Smyrk TC, Burdiles P, Hoeft SF, Peters JH, Kiyabu $\mathrm{M}$, et al. Is Barrett's metaplasia the source of adenocarcinoma of the cardia? Arch Surg 1994;129:609-14.

20. Wijnhoven BP, Siersema PD, Hop WC, van Dekken H, Tilanus HW. Adenocarcinomas of the distal oesophagus and gastric cardia are one clinical entity. Rotterdam Oesophageal Tumour Study Group. Br J Surg 1999;86:529-35. 